\title{
An Analysis of Central Drivers of REIT Returns
}

\author{
Jordan Joyce
}




\section{Abstract}

Many researchers have questioned whether real estate investment trusts (REITs) can act as a hedge for inflation or whether REITs can act as a safe haven for investors in the event of economic downturn. However, many studies lack basic data analysis or timely data to determine the dependence of REIT returns on various economic factors. The goal of this study is to act as a meta-analysis to synthesize the relationship between REITs and several potential risk factors. This study will extend beyond the timeline of previous studies, and will examine the relationship of several hypothesized risk factors. The results of this study can help brokers in their future decisions to hedge REIT risk in a portfolio.

This study will use the historical returns from the National Association of Real Estate Investment Trusts (NAREIT) as well as six indices. This study will also use both univariate regressions and multivariate regressions to analyze the relationship between REITs and mortgage REITs and each representative index

\section{Introduction}

A real estate investment trust (REIT) is a company that owns, operates, or finances incomegenerating real estate. REITs were established in 1960 by Congress. The provision allows investors to buy shares in commercial real estate portfolios. Prior to this 1960 provision, REITs were only available to the wealthy through large financial intermediaries.

REITs have been modeled after mutual funds. In this model, capital is pooled from numerous investors, making it possible for individual investors to earn dividends from real estate investments without the need to individually buy, manage, or finance a property. Through this structure, similar to mutual funds, REITs do generate a steady income stream for its investors, but don't offer much in the way of capital appreciation. An estimated 87 million U.S. investors own REITs through their retirement savings and other investment funds. Investors can purchase shares of REITS, REIT mutual funds, or REIT exchange-traded funds (ETFs) through a broker. Today, there are more than 225 publicly traded REITs in the United States.

Properties in a REIT portfolio may include a variety of properties, including apartment complexes, healthcare facilities, office buildings, retail, and warehouses. In general, REITs tend to specialize in a specific real estate sector. However, investors may choose to diversify their portfolios by holding different types of properties. The three main categories of REITs include Equity REITs, Mortgage REITs, and Hybrid REITs. Most REITs are Equity REITs, which own and manage income-producing real estate. Equity REITs primarily generate funds through the collection of rents. Mortgage REITs lend money to real estate operators and owners through mortgages and loans or through mortgage-backed securities, and earnings are generated primarily through the spread between the interest they earn on mortgage loans and the cost of funding the loans. Finally, Hybrid REITs combine the strategies of Equity and Mortgage REITs.

To qualify as a REIT, a company must meet certain provisions outlined in the Internal Revenue Code. First, a company must derive $75 \%$ of its gross income from rents, interest on mortgages that finance real property, or real estate sales. A company must also pay a minimum of $90 \%$ of taxable 
income in the form of shareholder dividends each year. Additionally, a company must invest at least $75 \%$ of total assets in real estate, cash, or U.S. Treasuries. A company must be an entity that is taxable as a corporation and be managed by a board of directors. A company must have at least one hundred shareholders after its first year of existence. Finally, a company must have no more than $50 \%$ of its shares held by five or fewer individuals.

If an investor is looking for a strong and stable annual dividend, a REIT is a great option. Today, it is estimated that REITs collectively own about $\$ 3$ trillion in gross assets, with publicly traded equity REITs accounting for $\$ 2$ trillion. Further, REITs total return has outperformed the S\&P 500 index for the last twenty years.

\section{Literature Review}

Many studies have revealed several factors that have correlative effects on REIT return. Literature has identified a multitude of different potential return drivers for REITs. Further, researchers have realized that the timeline during which these factors are analyzed has an impact on how closely correlated they are to REIT returns. This study will build on these insights by narrowing the expansive risk factors and updating the timeline.

\section{REIT Returns}

REIT total return is the combination of income returns from dividends and capital gains from share price appreciation. REITs are comparable to other assets, such as stocks and bonds, in their pricing structure. Many factors affect the value of a REIT's share price, with the primary factor being the earnings from rental revenue and the price-earnings multiple assigned by the marketplace. Therefore, there are a number of potential factors that can affect REIT return behavior. The returns of REITs are no more easily predicted than the returns of stocks. The level and growth of rents are largely determined by the supply and demand factors in real estate markets, such as population size, population growth, employment growth, construction, and the level of overall economic activity. The differences in these factors, by region and project, for example, have a direct impact on rents and occupancy rates, which affect projected earnings and property values. Idiosyncratic risk dominates the volatility of REIT returns and conditional idiosyncratic volatility impacts the cross-sectional returns of REIT stocks (Ledtin, 2019).

\section{Risk Factors}

Literature has suggested that macroeconomic variables such as inflation rate, industrial production growth, interest rates, U.S. stock market returns, consumer sentiment, policy uncertainty, market uncertainty, and leverage could all play a role in REIT returns. The factors appearing most frequently in literature are inflation and interest rates. 


\section{Interest Rates}

Many studies have examined the influence of interest-rate changes on REITs. This may appear to be the most obvious risk factor because the investment in real estate relies heavily on borrowed funds. Therefore, the general value of real estate can be influenced by the cost of financing. Rising interest rates may result in reduced demand for real estate, which can lower values. An increase in interest rates may cause a higher rate of debt financing and a higher required rate of return by real estate investors. Further, the cost to develop real estate during a cycle of climbing interest rates results in higher costs. All of this suggests that an increase in interest rates will lead to the fall of REIT returns.

Studies on the effect of interest rates on REIT returns lead to two differing positions. One body of research tends to find REIT returns more sensitive to interest rate changes, while the other finds little correlation between movement in interest rates and REIT returns. A large majority of these studies were conducted before the early 2000s and tend to cover different time periods and REIT characteristics. In a more recent study, it was concluded that interest rates impact REITs, though unevenly, depending on the particular time frame (Swanson, 2002).

\section{Inflation}

Throughout the literature, REITs are commonly investigated as a hedge for inflation. Whether the REIT is a hedge for inflation depends on the underlying real estate asset. It is common knowledge that housing prices tend to rise with inflation. Thus, many researchers believe that REIT values would appreciate with inflation. However, because REITs combine characteristics of unsecuritized real estate and common stock, the evidence on the ability of REITs to hedge inflation is mixed.

Empirical evidence tends to illustrate REITs as an irrational inflation hedge. Generally, the coefficients on expected inflation are positive or near 1, especially in the case of mortgage REITs; however, REITs perform poorly when measured against unexpected inflation. (Yobaccio, 1995). REITs are sometimes considered to move with inflation due to shifts in corresponding monetary policy (Chiuling, 2001). Thus, the success of REITs is loosely tied to inflation, but likely unexplained by its changes. 


\section{Data \& Methodology}

\section{Data}

Using the National Association of Real Estate Investment Trusts, I gathered monthly historical REIT return data from 1972 to 2020 . Monthly data on the 10-year treasury rate, crude oil prices, unemployment rate, and industrial production was collected from Federal Reserve Economic Data. Data on the Consumer Price Index was collected from the U.S. Bureau of Labor Statistics.

Because there is no perfect measure of interest rates, I chose to use the 10-year treasury rate for thisstudy. My preferred rate would have been the 30-year fixed rate mortgage, due to its direct correlation to real estate. However, there was no updated or accessible historical, monthly data for this rate. Therefore, the 10-year treasury rate was used as a proxy. The 10-year treasury rate is an acceptable proxy because it tends to closely follow the 30-year fixed rate mortgage over the relevant range.

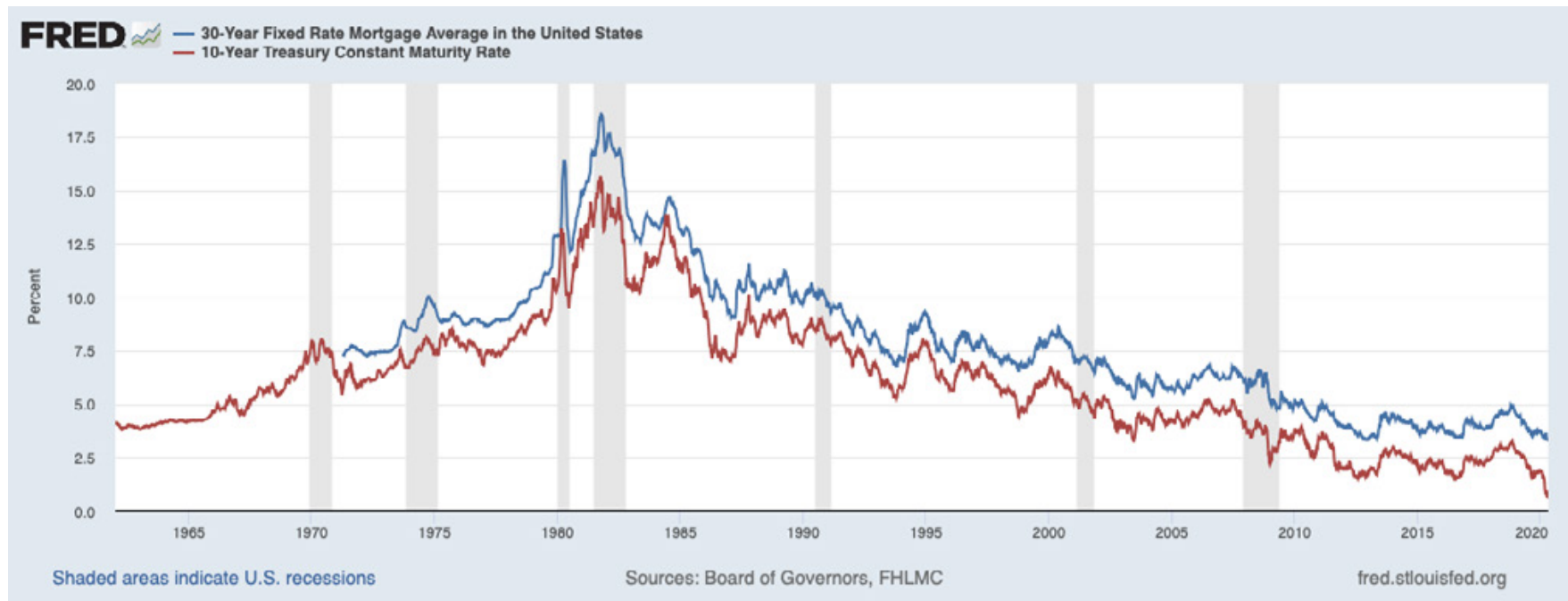

Consumer Price Index (CPI) was chosen to represent inflation because it is commonly equated to a measure of inflation that tracks the average change in prices over time. The CPI is the most widely watched and used measure of the U.S. inflation rate, and is used to determine real domestic gross product. Thus, CPI is often considered an appropriate proxy for inflation.

\section{Methodology}

From the data collected, I ran univariate regressions with the percentage change of each variable as the Input X Range and the percentage return of all REITs as the Input Y Range. This process was repeated for each risk factor as the Input X Range. Next, this process was repeated with Mortgage REITs as the Input Y Range. The data was then analyzed monthly from November 1, 2009 to January 1, 2020. For each regression summary, I analyzed the $\mathrm{R}$ squared to determine the relationship between the variable and the REIT. Then, I analyzed the beta and p-value to determine if this relationship was significant. 
To further verify the significance of each risk factor, I ran a multi-variate regression for all REITs and Mortgage REITs. By doing this, I allowed each factor to be compared over the same timeline. I verified significance based on the returned p-value.

\section{Results and Discussion}

All REITs Regressed Against Risk Factors

\begin{tabular}{|l|r|r|r|}
\hline & R Square & \multicolumn{1}{|c|}{ Beta } & \multicolumn{1}{c|}{-value } \\
\hline 10 Year Treasury & 0.01293389 & -0.1040755 & 0.00615267 \\
\hline SPY (Market Index) & 0.32451786 & 0.7187334 & $1.9294 \mathrm{E}-29$ \\
\hline Consumer Price Index & 0.24859364 & 2.4573975 & $3.2713 \mathrm{E}-09$ \\
\hline Oil Index & 0.00390908 & 0.03478396 & 0.20646029 \\
\hline Unemployment Rate & 0.00764735 & 0.06146991 & 0.03540272 \\
\hline Industrial Production & 0.00038826 & 0.13255371 & 0.63610428 \\
\hline
\end{tabular}

The chart above summarizes the relevant results of six univariate regressions. To identify which variables are significant in regard to REITs, I determined which variables had a p-value of less than 0.05. The variables that are deemed statistically significant are the 10-year treasury rate, market index, and consumer price index. All other variables can be disregarded as random.

The most significant variable identified is the market index. Per this analysis, one-third of the total movement in REITs is explained by the market. If the market does well, REITs will improve similarly.

Consumer Price Index is the next and most significant factor in the analysis of all REITs. Per this analysis, if inflation goes up, REITs go up. In this regression, inflation explains $25 \%$ of the movement of REITs.

Finally, the 10-year treasury, which is representative of interest rates, is the least significant risk factor to REITs. This regression confirms the belief that as interest rates rise, REIT returns decline. Only around $1 \%$ of the movement of REITs is explained by interest rates. 
Mortgage REITs Regressed Against Risk Factors

\begin{tabular}{|l|r|r|r|}
\hline & \multicolumn{1}{|c|}{ R Square } & \multicolumn{1}{|c|}{ Beta } & \multicolumn{1}{|c|}{-value } \\
\hline 10 Year Treasury & 0.00014136 & -1.307104 & 0.77527624 \\
\hline SPY (Market Index) & 0.19034666 & 0.66771922 & $1.398 \mathrm{E}-16$ \\
\hline Consumer Price Index & 0.3197691 & 3.71511756 & $6.3819 \mathrm{E}-12$ \\
\hline Oil Index & 0.00811468 & 0.06037216 & 0.06843238 \\
\hline Unemployment Rate & 0.01640898 & 0.10817032 & 0.00201232 \\
\hline Industrial Production & 0.00088805 & 0.24083114 & 0.47419187 \\
\hline
\end{tabular}

The significant risk factors for Mortgage REITs vary slightly from those for all REITs. Interest rates are no longer statistically significant when Mortgage REITs are regressed against risk factors. The market does not explain movements in the Mortgage REITs as much as it does in all REITs. However, the market is still a significant factor. Inflation becomes slightly more significant, increasing to $32 \%$ of explained movement.

\section{All REITs Multivariate Regression}

\begin{tabular}{|c|c|c|c|c|c|c|c|c|}
\hline \multicolumn{9}{|l|}{ SUMMARY OUTPUT } \\
\hline \multicolumn{9}{|c|}{ Regression Statistics } \\
\hline Multiple R & 0.6913 & & & & & & & \\
\hline R Square & 0.4779 & & & & & & & \\
\hline Adjusted R Square & 0.4509 & & & & & & & \\
\hline Standard Error & 0.0304 & & & & & & & \\
\hline Observations & 123.0000 & & & & & & & \\
\hline \multirow{2}{*}{\multicolumn{9}{|c|}{ ANOVA }} \\
\hline & & & & & & & & \\
\hline & $d f$ & $S S$ & $M S$ & $F$ & Significance $F$ & & & \\
\hline Regression & 6.0000 & 0.0981 & 0.0164 & 17.6952 & 0.0000 & & & \\
\hline Residual & 116.0000 & 0.1072 & 0.0009 & & & & & \\
\hline \multirow[t]{2}{*}{ Total } & 122.0000 & 0.2053 & & & & & & \\
\hline & Coefficients & Standard Error & $t$ Stat & $P$-value & Lower 95\% & Upper 95\% & Lower $95.0 \%$ & Upper $95.0 \%$ \\
\hline Intercept & 0.0030 & 0.0030 & 0.9799 & 0.3292 & -0.0030 & 0.0090 & -0.0030 & 0.0090 \\
\hline 10Y Treasury & -0.1109 & 0.0435 & -2.5468 & 0.0122 & -0.1971 & -0.0246 & -0.1971 & -0.0246 \\
\hline SPY & 0.8474 & 0.0999 & 8.4860 & 0.0000 & 0.6496 & 1.0452 & 0.6496 & 1.0452 \\
\hline CPI & -0.1516 & 0.4172 & -0.3633 & 0.7170 & -0.9778 & 0.6747 & -0.9778 & 0.6747 \\
\hline Oil & -0.0275 & 0.0417 & -0.6591 & 0.5111 & -0.1101 & 0.0551 & -0.1101 & 0.0551 \\
\hline Unemployment & 0.0719 & 0.0442 & 1.6256 & 0.1067 & -0.0157 & 0.1595 & -0.0157 & 0.1595 \\
\hline Industrial Productior & 0.3356 & 0.5732 & 0.5855 & 0.5593 & -0.7996 & 1.4708 & -0.7996 & 1.4708 \\
\hline
\end{tabular}

To further test the validity of the relationships between risk factors and REITs, I performed a multivariate regression. This regression resulted in the re-emphasis of the statistical significance of the market and interest rates on REIT returns. However, inflation was no longer recognized as significant. The combination of market influences and interest rate changes accounted for nearly $48 \%$ of REIT returns. 
Mortgage REIT Multivariate Regression

\begin{tabular}{|c|c|c|c|c|c|c|c|c|}
\hline SUMMARY OUTPL & & & & & & & & \\
\hline \multicolumn{9}{|c|}{ Regression Statistics } \\
\hline Multiple R & 0.5482 & & & & & & & \\
\hline R Square & 0.3005 & & & & & & & \\
\hline Adjusted R Square & 0.2643 & & & & & & & \\
\hline Standard Error & 0.0308 & & & & & & & \\
\hline Observations & 123.0000 & & & & & & & \\
\hline \multicolumn{9}{|l|}{ ANOVA } \\
\hline & $d f$ & $S S$ & $M S$ & $F$ & Significance $F$ & & & \\
\hline Regression & 6.0000 & 0.0472 & 0.0079 & 8.3048 & 0.0000 & & & \\
\hline Residual & 116.0000 & 0.1100 & 0.0009 & & & & & \\
\hline \multirow[t]{2}{*}{ Total } & 122.0000 & 0.1572 & & & & & & \\
\hline & Coefficients & Standard Error & $t$ Stat & $P$-value & Lower 95\% & Upper $95 \%$ & Lower $95.0 \%$ & Upper $95.0 \%$ \\
\hline Intercept & 0.0044 & 0.0031 & 1.4159 & 0.1595 & -0.0017 & 0.0104 & -0.0017 & 0.0104 \\
\hline 10Y Treasury & -0.0540 & 0.0441 & -1.2244 & 0.2233 & -0.1413 & 0.0333 & -0.1413 & 0.0333 \\
\hline SPY & 0.4034 & 0.1011 & 3.9890 & 0.0001 & 0.2031 & 0.6038 & 0.2031 & 0.6038 \\
\hline CPI & 0.9079 & 0.4225 & 2.1488 & 0.0337 & 0.0710 & 1.7448 & 0.0710 & 1.7448 \\
\hline Oil & 0.0024 & 0.0422 & 0.0575 & 0.9542 & -0.0813 & 0.0861 & -0.0813 & 0.0861 \\
\hline Unemployment & 0.0077 & 0.0448 & 0.1712 & 0.8644 & -0.0810 & 0.0964 & -0.0810 & 0.0964 \\
\hline Industrial Production & -0.1842 & 0.5805 & -0.3173 & 0.7516 & -1.3339 & 0.9656 & -1.3339 & 0.9656 \\
\hline
\end{tabular}

As for Mortgage REITs, the market was the only remaining statistical significance after performing the multi-variate regression. The market explains 30\% of Mortgage REIT returns.

\section{Conclusion}

This study examined six risk factors to REITs that have been commonly mentioned in current literature. The data I analyzed suggested that the only statistically significant factors to REITs are primarily market influences and, to a lesser degree, interest rates. Mortgage REITs are only found to be impacted by the market index.

This study largely supports the idea that REIT returns are not predictable, as their return structure is similar to that of stocks and bonds. Future studies could identify how to hedge the residuals of such regressions or expand on the risk factors tested. These studies could run hundreds of other regressions using daily, monthly, and yearly data to determine the strength of these findings and to confirm a true relationship between REIT returns and the risk factors studied here.

Conducting this study taught me to be a more a more critical reader, and to question the validity of headlines about this asset class. Some of the most commonly reported assertions about factors that drive REIT returns could not be proven factual in this study. I look forward to continuing in the real estate finance field with a newfound healthy cynicism. 


\section{References}

Akinsomi, Omokolade, et al, "Real Estate Returns Predictability Revisited: Novel Evidence from the US REITs Market." Empirical Economics, vol. 51, no. 3, Nov. 2016 https://doi.org/10.1007/s00181-015$\underline{1037-5}$

Allen, Marcus T., and Jeff Madura. "REIT Characteristics and the Sensitivity of REIT Returns." Journal of Real Estate Finance Eீ Economics, vol. 21, no. 2, Sept. 2000 https://doi. org/10.1023/A:1007839809578

Bodie, Kane, and Marcus, Investments. New York: McGraw-Hill Education. 2014.

Chiuling Lu, and Raymond. So. "The Relationship Between REITs Returns and Inflation: A Vector Error Correction Approach.” Review of Quantitative Finance E् Accounting, vol. 16, no. 2, Mar. 2001 https://doi.org/10.1023/A:1011225723400

Goebel, Paul, et. al. "REIT Momentum and Characteristic-Related REIT Returns." Fournal of Real Estate Finance E Economics, vol. 47, no. 3, Oct. 2013 https://doi.org/10.1007/s11146-012-9371-2

"Federal Reserve Economic Data: FRED: St. Louis Fed." FRED, Federal Reserve Bank of St. Louis, fred.stlouisfed.org/. https://fred.stlouisfed.org/fred-mobile/index.php

Letdin, Mariya, et al. "Explaining Reit Returns.” Journal of Real Estate Literature, vol. 27, no. 1, Jan. 2019 https://doi.org/10.5555/0927-7544.27.1.1

NAREIT. "REITs \& Real Estate Investing: Real Estate Working For You: Nareit." REITs \&̊ Real Estate Investing | Real Estate Working For You | Nareit, www.reit.com/.

Swanson, Zane et. al "REIT Risk Premium Sensitivity and Interest Rates." Fournal of Real Estate Finance E Economics, vol. 24, no. 3, May 2002 https://doi.org/10.1023/A:1015273532625

Yobaccio, Elizabeth, et al. "The Inflation-Hedging Properties of Risk Assets: The Case of REITs." Fournal of Real Estate Research, vol. 10, no. 3, May 1995 https://doi.org/10.1080/10835547 